\title{
Comments on protection of geological sites in Greenland
}

Greenland is a large land with unique arctic nature which also offers just as unique opportunities to the geologist. The rocks range from the very oldest Precambrian to the most recent glacial deposits. The degree of weathering is minimal and fresh outcrops can be studied nearly everywhere. Greenland has attracted scientists from all over the world for many years and has become a centre of international geological research.

It must sadden all Greenland geologists to read "Wanton disfiguration of famous Skaergaard outcrop deplored" that forms the first article in "Report of Activities, 1977'. All must agree with the authors that such things should not occur. It would be extremely difficult if not impossible to protect all geological localities by law. Nor would it be possible to make a complete catalogue of every area that should be protected or indeed how they could be protected in such a region as vast as Greenland. One can draw attention to many examples such as the authors have done with Skaergaard. However, this should not be necessary. The best protection would be if the individual geologist developed a sense of responsibility both towards Greenland's nature and towards other geologists so that they themselves would feel as the authors of the article have done when confronted with wanton damage.

It is my opinion that publication of this article takes us a major step forward in our efforts to keep and protect unusual and classical geological localities in Greenland.

K. Ellitsgaard-Rasmussen 